\title{
Field Screening of Lesotho and South African Wheat Cultivars for Russian Wheat Aphid Resistance
}

\author{
Astrid Jankielsohn ${ }^{1}$, Pitso Masupha², Lintle Mohase ${ }^{3}$ \\ ${ }^{1}$ Crop Protection, ARC-Small Grain Institute, Bethlehem, South Africa \\ ${ }^{2}$ Department Crop Protection, National University of Lesotho, Roma, Lesotho \\ ${ }^{3}$ Department of Plant Physiology, University of the Free State, Bloemfontein, South Africa \\ Email: *jankielsohna@arc.agric.za
}

How to cite this paper: Jankielsohn, A., Masupha, P. and Mohase, L. (2016) Field Screening of Lesotho and South African Wheat Cultivars for Russian Wheat Aphid Resistance. Advances in Entomology, 4, 268278.

http://dx.doi.org/10.4236/ae.2016.45028

Received: August 10, 2016

Accepted: October 21, 2016

Published: October 24, 2016

Copyright $\odot 2016$ by authors and Scientific Research Publishing Inc. This work is licensed under the Creative Commons Attribution International License (CC BY 4.0).

http://creativecommons.org/licenses/by/4.0/ (c) (i) Open Access

\section{Abstract}

Russian wheat aphid (Diuraphis noxia) is an international wheat pest and was first recorded in South Africa in 1978 in the Bethlehem area in the Eastern Free State. Lesotho lies adjacent to one of the largest wheat producing areas in South Africa, the Eastern Free State, where winter wheat and facultative types are cultivated under dry land conditions. Wheat (Triticum aestivum L.) is an important crop adapted to all agro-ecological zones of Lesotho. Russian wheat aphid may have a significant impact on wheat yield. No monitoring or pest control is being done in Lesotho and at this stage there is very little information on the Russian wheat aphid resistance of wheat cultivars cultivated in Lesotho. In view of this it is important to monitor the distribution of Russian wheat aphid biotypes in Lesotho and determine the level of Russian wheat aphid resistance in local Lesotho wheat cultivars. Two local Lesotho wheat cultivars, Bolane and Makalaote were screened together with South African cultivars Elands, Matlabas, Senqu, PAN3379, PAN3118 and SST387, in the glasshouse against all four known biotypes that occur in South Africa. All these cultivars were also planted in $5 \mathrm{~m}$ plots in the field at two localities Leribe and Roma in the lowlands of Lesotho. These cultivars were screened in the field for Russian wheat aphid resistance. The predominant Russian wheat aphid biotypes in these areas were also determined. The Lesotho cultivar, Bolane had resistance against RWASA2 in the glasshouse, while Makalaote did not have any Russian wheat aphid resistance in either the glasshouse or field screenings. To contribute to food security an increasing wheat yield potential is a high priority. Russian wheat aphid has been included in the list of important international cereal pests. Russian wheat aphid adapts to changing environments and taking their ecology, distribution, virulence patterns, and variability into account is important in minimizing the gap between actual and attainable yields. 
Current management practices for winter wheat in South Africa include the use of resistant cultivars, which is the most economical management strategy for Russian wheat aphid. Introducing Russian wheat aphid resistant cultivars in Lesotho will improve overall yield and as a result food security. This will also result in lower Russian wheat aphid pest pressure in the adjacent wheat production areas in the Eastern Free State, South Africa.

\section{Keywords}

Russian Wheat Aphid Biotypes, Wheat Cultivars, Lesotho, Field Screening, Resistance

\section{Introduction}

Russian wheat aphid (Diuraphis noxia (Kurdjumov)) has spread from its native area in central Asia [1] to all the major wheat producing countries in the world, becoming an international wheat pest. It is considered a primary pest of dryland winter wheat in North America [2] and South Africa [3]. Russian wheat aphid belongs to the group of alien aphid species that are capable of surviving even at low numbers for a relatively long time and also causing population outbreaks in new areas [4]. The first authentic record of Russian wheat aphid outside its original area of distribution was in South Africa in 1978. Initially the distribution was confined to the Bethlehem area in the Eastern Free State, but by 1979 the Russian wheat aphid had spread to other wheat producing areas in the country [3]. The first record of Russian wheat aphid in the United States was in 1986 [2]. Russian wheat aphid invaded all the Central European countries form the south-east [5] and was first detected in the Czech Republic in 1993 [6] [7]. The most effective management option for Russian wheat aphid is the cultivation of Russian wheat aphid resistant wheat. Russian wheat aphid resistant wheat does not exhibit the typical Russian wheat aphid damage symptoms of susceptible wheat, but the level of resistance may vary and it is important to categorize resistance in a breeding program so that wheat can be developed with combinations of resistance [8]. A further challenge in wheat breeding programs is that the pest insect changes and adapts to changing environments leading to new damaging biotypes. There are currently four Russian wheat aphid biotypes known in South Africa. These biotypes differ in their virulence against different wheat cultivars with different resistance genes. RWASA1 is the first biotype that was recorded in 1978 [3]. RWASA2, relatively unaffected by the Dn1 resistant gene in wheat, was reported in 2005 [9]. RWASA3, relatively unaffected by the Dn4 resistant gene in wheat, was reported in 2009 [10]. During 2011, RWASA4, relatively unaffected by the $D n 5$ resistant gene, was reported [11].

Lesotho is a land locked country bordered in the north-west by the Eastern Free State (a dryland wheat production area), north-east by KwaZulu-Natal and south by the Eastern Cape (Figure 1). The country is divided into four agro-ecological zones which are characterized by significant climatic and ecological differences [12]. The lowlands 


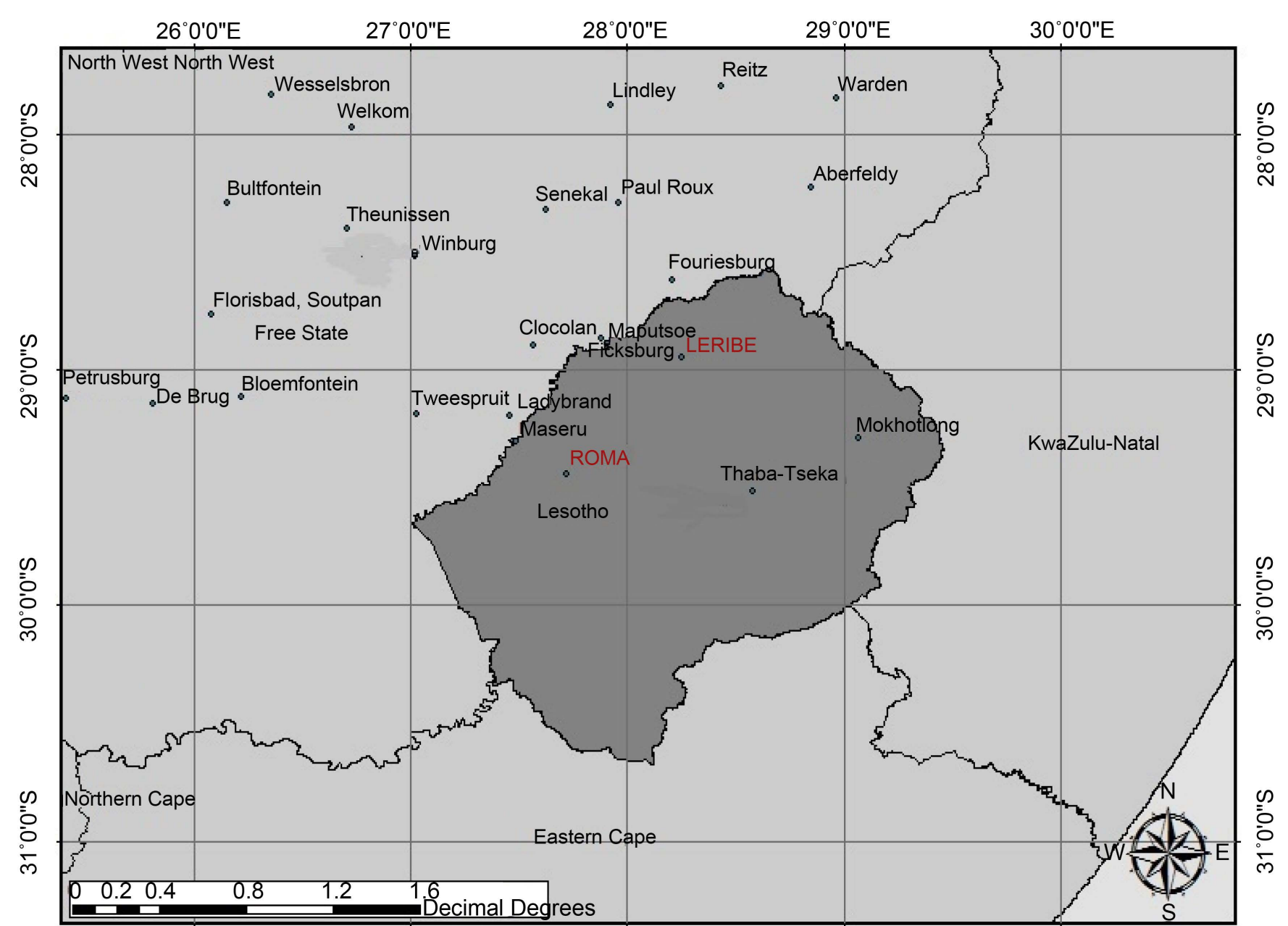

Figure 1. Trial sites Leribe and Roma in Lesotho.

have a relatively high rainfall that allows for cultivation of maize, sorghum, beans, winter wheat and vegetables. The foothills lie between 1800 and 2400 meters above sea level and maize, sorghum and summer peas are cultivated in this zone. The mountain zone is characterized by very cold winters and rises to an elevation of 3500 meters above sea level. This makes this area unsuitable for cultivation of most crops and only winter wheat is cultivated in this area, making it the biggest wheat production area in the country. The Senqu River valley is a steep along the Senqu River, which runs from east to west across the country. The valley is characterized by a low rainfall. Winter wheat and maize are grown in this valley.

Wheat (Triticum aestivum L.) is an important crop adapted to all agro-ecological zones of Lesotho. Winter wheat is grown in the lowlands, foothills, the Senqu River Valley and spring wheat in the mountain areas [12]. The most commonly grown cultivars in Lesotho are Bolane, Makalaote, Mants'a Tlala and Mohohlotsane [13]. In the areas in the mountains in Mokhotlong (Malefiloane) and Thaba-Tseka (Lesobeng and Mant'sonyana), where maize production is not successful, the farmers mainly grow wheat as a cereal crop and the most commonly grown cultivars in these areas are Bo- 
lane and Makalaote. Bolane is a tall cultivar which was introduced to Lesotho in the sixties. The cultivar is used for bread making and its tall straw length also makes it suitable for roofing. Bolane is a soft, white wheat and farmers prefer it for its superior bread making qualities.

Farmers in Lesotho still rely on recycled seed, do not use fertilizers and use ox drawn implements to prepare the seedbed. Farmers in these areas also do not monitor their fields for possible pests and diseases, but only visit the fields when wheat is ready for harvesting. There is no Russian wheat aphid management program, neither through insecticide use nor resistant cultivars, in Lesotho. The cultivars used by the local farmers still have to be evaluated, as they may be some of the old varieties released in South Africa given the local names by the farmers. It is therefore necessary to determine the level of resistance against Russian wheat aphid biotypes in the local wheat cultivars commonly planted in Lesotho. It is also necessary to determine the Russian wheat aphid biotypes occurring in the wheat production areas of Lesotho. It is also believed that current varieties available on the market in South Africa might perform better than local varieties in terms of yield and tolerance to pests and diseases.

\section{Material and Methods}

\subsection{Glasshouse Screening}

Two local Lesotho wheat cultivars, Bolane and Makalaote were screened together with South African dryland wheat cultivars Elands, Matlabas, Senqu, PAN3379, PAN3118 and SST387, with known Russian wheat aphid resistance, in the glasshouse against all four known Russian wheat aphid biotypes occurring in South Africa. Elands, Matlabas and Senqu contain the Dnlresistant gene and are resistant against RWASA1, PAN3379 is resistant to all four South African biotypes and PAN3118 and SST387 are susceptible to Russian wheat aphid and contain no Russian wheat aphid resistance genes.

Ten seeds of each plant entry were planted in a seedling tray filled with sterilized sand in a randomized complete block design with four replications for each cultivar. Plant entries were randomly assigned to rows and were separated by border rows planted with Russian wheat aphid susceptible Tugela. Plants were kept in glasshouse cubicles at night/day temperatures of $12^{\circ} \mathrm{C} / 22^{\circ} \mathrm{C}$, natural light (light/dark periods of 14 $\mathrm{h} / 10 \mathrm{~h}$ ). Immediately after planting, the seedling trays were placed in gauze (315 micron) cages to avoid contamination by secondary aphids. Plants were separately infested at the two-leaf stage with the four different Russian wheat aphid biotypes. Each plant was infested with 5 apterae, adult females. Plants were rated with a ten-point damage rating scale, which included leaf chlorosis and leaf rolling [14]. A score from 1 4 describes leaf chlorosis; 5 - 6 striping on the leaves and 7 - 10 rolling. As soon as the susceptible wheat Tugela showed susceptible damage symptoms all plants were rated. Cultivars were classified as susceptible or resistant by using damage ratings for each plant entry where the plant was considered resistant $(R)$ if the damage rating was $1-6.5$ and susceptible $(\mathrm{S})$ if the damage rating was 6.6 - 10 . 


\subsection{Field Screening}

A field trial was planted in the lowlands of Lesotho in plots at two localities, Leribe $\left(\mathrm{S} 29.03115^{\circ} \mathrm{E} 27.74461^{\circ}\right)$ and Roma (S29.44447 $\left.{ }^{\circ} \mathrm{E} 27.71944^{\circ}\right)$ (Figure 1) on 22/05/2015 and 29/05/2015 respectively. The trials were planted in $5 \mathrm{~m} \times 5$ row plots in a complete randomized block design with eight cultivars, Elands, Matlabas, Senqu, PAN3118, PAN3379, SST387, Makaloate and Bolane and four replications. Trials were planted with a tractor-drawn planter and soil was fertilized with chemical fertilizer. These trials were evaluated for Russian wheat aphid damage on 19/10/2015. The cultivars were evaluated in the field at adult stage on a 1-4-point scale where 1-no damage: Escape/ Resistant (R); 2-chloretic spots on leaves: Resistant (R); 3-longitudinal striping on leaves: Medium susceptible (MS); 4-rolling of leaves: susceptible (S).

Russian wheat aphid damage rating across all cultivars were analysed using a two-way (damage rating, cultivar) analysis of variance (ANOVA). Mean damage rate entries with significant $(\mathrm{P}<0.05)$ clone-by-plant interactions were separated by Fisher's protected least significant difference (LSD) test at the $5 \%$ level.

\subsection{Russian Wheat Aphid Biotype Determination}

Russian wheat aphid samples were collected at each trial site by placing an infested wheat leaf in a petri dish and sealing it with parafilm. Each leaf collected was infested with between 20 and a 100 Russian wheat aphids. Three leaf samples were collected from Bolane and three from Makaloate at both Leribe and Roma trial sites. Samples were transported back to the glasshouse in an icebox. An individual aphid from each sample collected in the field was transferred to a wheat plant and caged (gauze size: 315

Table 1. Differential used to designate new Russian wheat aphid biotypes in South Africa (original seed obtained from USDA-ARS, Stillwater, OK).

\begin{tabular}{cccc}
\hline no & Gene & ID & Resistance source \\
\hline 1 & $D n 1$ & CO-03797 & PI127739 \\
2 & $D n 2$ & CO-03804 & PI262660 \\
3 & $D n 3$ & CO-03811 & Triticum tauschii line SQ24 \\
4 & $D n 4$ & Yumar & PI372129 \\
5 & Dn5 & CO-950043 & PI294994 \\
6 & Dn6 & CI 6501 & PI243781 \\
7 & Dn7 & $2003-1378027$ Winter & 94 M370 \\
8 & Dn8 & Karee-Dn8 & PI294994 \\
9 & Dn9 & Betta-Dn9 & PI294994 \\
10 & Dnx & 2006 RWA-1 & PI220127 \\
11 & Dny & 2006 RWA-1 Stanton & PI220350 \\
12 & Susceptible check & Tugela Susceptible & - \\
13 & Resistant check & RWA Matrix 2401 & CItr2401 \\
\hline
\end{tabular}


micron) to produce a clone colony. Colonies were kept in a greenhouse cubicle at night/day temperatures of $16^{\circ} \mathrm{C} / 22^{\circ} \mathrm{C}$. Clone colonies were maintained on different cultivars to avoid pre-adaptation to a specific cultivar until they multiplied sufficiently to be used for screening. Each clone colony was cultured for an average period of one to two months before screening.

The biotype of each RWA clone was determined by screening its feeding damage on 11 previously established plant resistant sources containing designated resistance genes $D n 1$ to $D n 9$ and Dnx and Dny (Table 1). Infestations of RWASA1 cause susceptible damage symptoms on wheat entries containing the $D n 2$ and $D n 3$ gene. RWASA2 cause susceptible damage symptoms on wheat entries containing $D n 1, D n 2, D n 3, D n 8$ and $D n 9$ resistance genes. RWASA3 is distinguished from RWASA2 by its added virulence to Dn4 and RWASA4 is distinguished from RWASA3 by its added virulence to Dn5. Ten seeds of each plant entry were planted in a seedling tray filled with sterilized sand in a randomized complete block design with four replications for each biotype determination. Plant entries were randomly assigned to rows and were separated by border rows planted with RWA susceptible Tugela. Plants were kept in greenhouse cubicles at night/day temperatures of $12^{\circ} \mathrm{C} / 22^{\circ} \mathrm{C}$, natural light (light/dark periods of $14 \mathrm{~h} / 10 \mathrm{~h}$ ). Immediately after planting, the seedling trays were placed in gauze ( 315 micron) cages to avoid contamination by secondary aphids. Plants were infested at the two-leaf stage with RWA clone colonies. Each plant was infested with 5 apterae, adult females. Plants were rated with a ten-point damage rating scale, which included leaf chlorosis and leaf rolling [14]. A score from 1 - 4 describes leaf chlorosis; 5 - 6 striping on the leaves and 7 10 rolling. Once the susceptible wheat Tugela showed susceptible damage symptoms all plants were rated. RWA biotypes were classified by using damage ratings for each plant entry where the plant was considered resistant $(\mathrm{R})$ if the damage rating was $1-6.5$ and susceptible (S) if the damage rating was 6.5 - 10. Each clone was given a biotype designation based on the differential virulence profile to the $D n 1$ to $D n 9$ resistance genes.

Biotype (clones) groups across all plant differentials were analysed using a two-way (clone, plant entry) analysis of variance (ANOVA). Mean damage rate entries with significant $(\mathrm{P}<0.05)$ clone-by-plant interactions were separated by Fisher's protected least significant difference (LSD) test at the $5 \%$ level.

\section{Results}

\subsection{Glasshouse Screening}

The glasshouse screening showed that the South African cultivars Elands, Matlabas, Senqu and SST387 had sufficient resistance against RWASA1, but were susceptible to the other three Russian wheat aphid biotypes (Table 2). PAN3379 had sufficient resistance against all the Russian wheat aphid biotypes, while PAN3318 was susceptible to all the Russian wheat aphid biotypes (Table 2). The Lesotho cultivar Makaloate was susceptible to all the Russian wheat aphid biotypes, while the Lesotho cultivar Bolane had sufficient resistance against only RWASA2 and not the other Russian wheat aphid biotypes (Table 2). Depending on the prevailing Russian wheat aphid biotypes these 
Table 2. Russian wheat aphid resistant/susceptible (R: Resistant; S: Susceptible) reaction of wheat cultivars in South Africa and Lesotho.

\begin{tabular}{ccccc}
\hline Cultivar & RWASA1 & RWASA2 & RWASA3 & RWASA4 \\
\hline Elands & R & S & S & S \\
Matlabas & R & S & S & S \\
Senqu & R & S & S & S \\
PAN3379 & R & R & R & R \\
PAN3318 & S & S & S & S \\
SST387 & R & S & S & S \\
Makaloate & S & S & S & S \\
Bolane & S & R & S & S \\
\hline
\end{tabular}

cultivars will be differently suited for cultivation in different areas. PAN3379 has resistance against all the known South African biotypes and can therefore be cultivated in an area where all the biotypes occur, while Elands, Matlabas, Senqu and SST387 will only offer resistance against Russian wheat aphid in areas where only RWASA1 occurs. Bolane will offer resistance where RWASA2 occurs and Makaloate and PAN3318 will offer no resistance where any of the Russian wheat aphid biotypes occur.

\subsection{Field Screening}

Analysis of the main effects of damage rating for the eight different wheat cultivars indicated a significant locality $(\mathrm{F}=7.23 ; \mathrm{df}=1 ; \mathrm{P}<0.0001)$, cultivar $(\mathrm{F}=48.92 ; \mathrm{df}=5 ; \mathrm{P}<$ $0.0001)$ and locality-by-cultivar interaction $(\mathrm{F}=5.13$; $\mathrm{df}=5 ; \mathrm{P}<0.0001)$. Since all the cultivars were evaluated in the same areas with similar Russian wheat aphid pressure it can be concluded that the cultivars responded differently to the Russian wheat aphid feeding at the different localities. There was a significant difference in the Russian wheat aphid damage ratings of Elands, Matlabas, SST387 and Makaloate between the two different localities (Figure 2). Even though there were differences in the reaction of the cultivars to the feeding of Russian wheat aphid at the different localities, the South African cultivars consistently had a lower damage rating than the Lesotho cultivars at both localities (Figure 2).

The Lesotho cultivars had a higher Russian wheat aphid damage rating than the South African cultivars at both localities indicating the Lesotho cultivars were more susceptible to Russian wheat aphid infestation than the South African cultivars (Figure 2). Bolane, however, had a lower damage rating than Makaloate and was more resistant against Russian wheat aphid infestation (Figure 2). The field screening reflects the glasshouse screening, with the South African cultivars showing more resistance against Russian wheat aphid than the Lesotho cultivars and Bolane having some degree of resistance.

\subsection{Russian Wheat Aphid Biotype Determination}

Russian wheat aphid biotypes collected at the trial site at Leribe were RWASA2, 


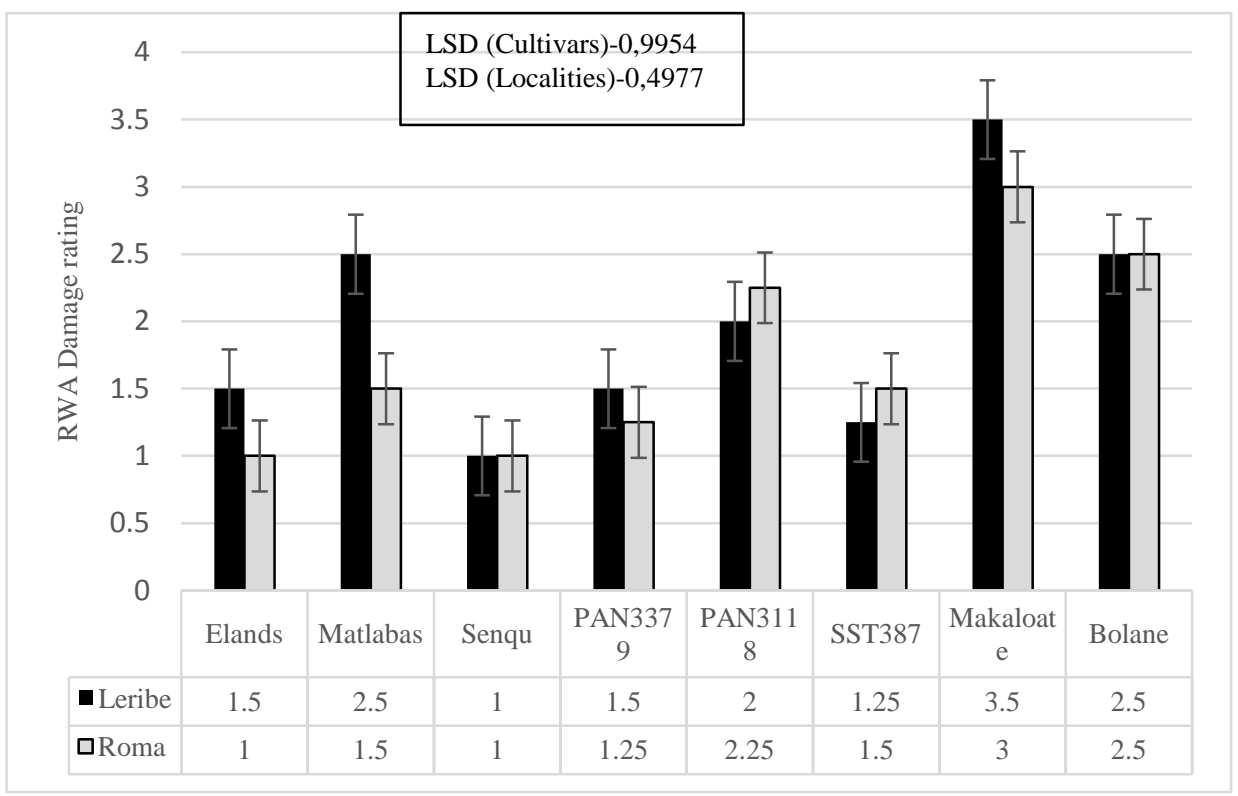

Figure 2. Russian wheat aphid damage rating for South African and Lesotho cultivars in field trials at Leribe and Roma.

RWASA3 and RWASA4 and at the trial site at Roma were RWASA1 and RWASA3 (Figure 3).

These biotypes were similar to those occurring in the Eastern Free State in the area of the towns Fouiesburg, Ficksburg and Clocolan, South Africa (Figure 3), indicating that there might be a movement of Russian wheat aphid between the Eastern Free State and Lesotho. The occurrence of all four Russian wheat aphid biotypes in Lesotho indicates that the local Lesotho cultivars do not have sufficient resistance against the prevailing Russian wheat aphid.

\section{Discussion}

In the glasshouse screening the Lesotho cultivar Makaloate had no resistance against any of the known Russian wheat aphid biotypes, while Bolane had resistance to only RWASA2. Since all the known Russian wheat aphid biotypes in South Africa also occurred in Lesotho the local Lesotho cultivars did not have sufficient resistance for management of the prevailing Russian wheat aphid biotypes. After the release of Russian wheat aphid resistant cultivars by the ARC-SGI in 1993 farmers in South Africa rapidly adopted these cultivars and the area sown to the cultivars increased from $3 \%$ in 1993 to $46 \%$ in 1997 [15]. Resistance in a cultivar reduces the population development of Russian wheat aphid [16] and Russian wheat aphid biomass is significantly higher on susceptible wheat and barley than on resistant wheat and oats [17]. This indicates that resistance in wheat can significantly reduce a population of Russian wheat aphid resulting in reduced pest pressure and damage to wheat. Wheat yield decreases as aphid densities increase in susceptible wheat, but yield remains constant regardless of initial aphid abundance in resistant wheat at different localities, confirming that the expression 


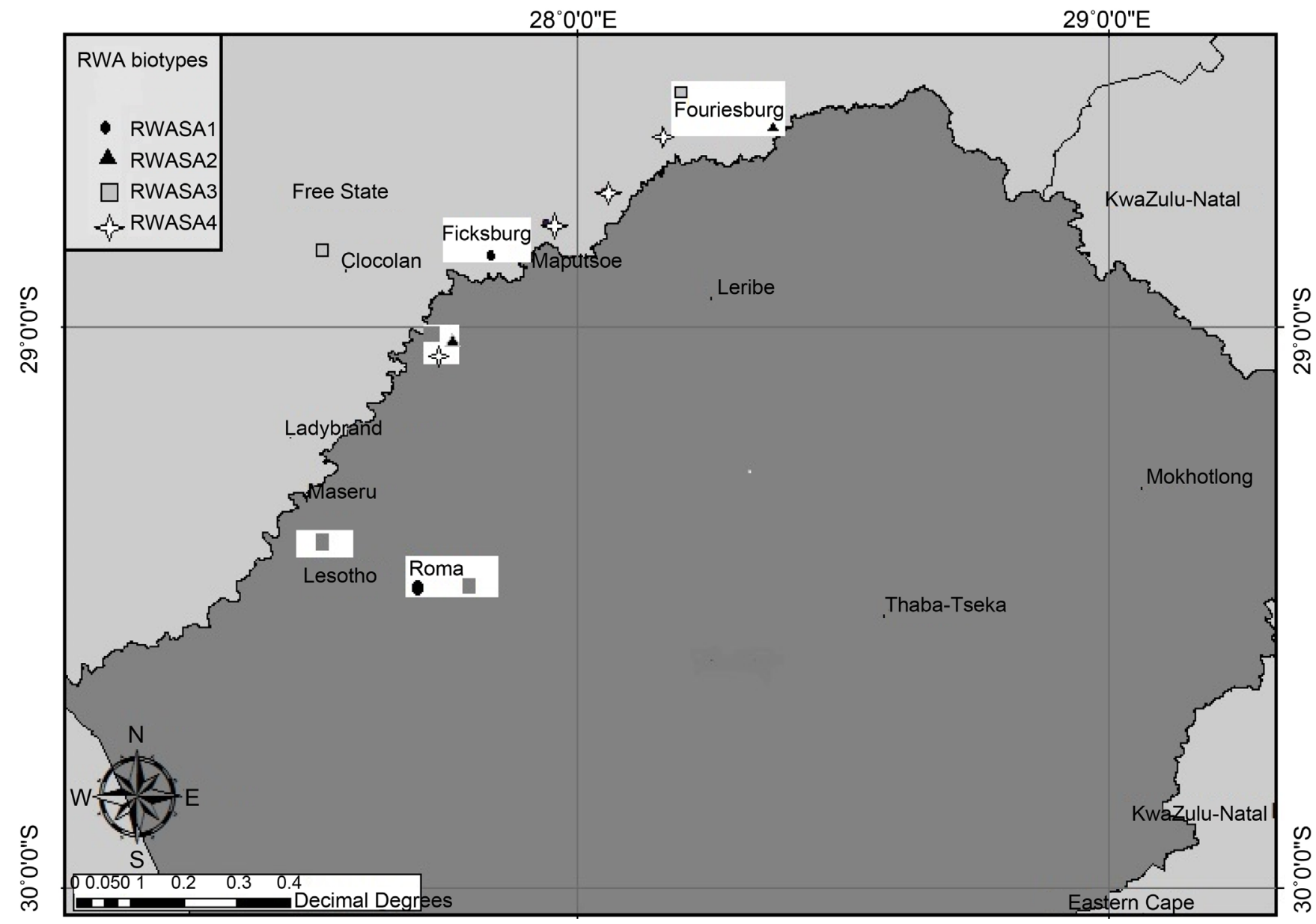

Figure 3. Russian wheat aphid biotypes occurring at the wheat trial sites in Lesotho and surrounding areas.

of resistance is affected by genetic background [18]. In South Africa (Central Free State, Eastern Free State and Thaba Nchu) Russian wheat aphid resistant wheat cultivars demonstrated a yield advantage over the susceptible cultivars [15]. There is therefore a link between Russian wheat aphid resistant cultivars and yield and cultivating Russian wheat aphid resistant cultivars in an area where Russian wheat aphid occurs might result in an increased yield in these areas. The average wheat yield for Lesotho is 1.1 ton/ha and Mokhotlong and Thaba-Tseka had an average yield of 1.66 ton/ha and 1.05 ton/ha respectively during the 2013-2014 season [12]. This is far below that of the neighbouring province, Free State, in South Africa, where Russian wheat aphid resistant cultivars are cultivated, with 2.90 ton/ha in the same season [19]. South African dryland cultivars screened in Lesotho showed better resistance to Russian wheat aphid biotypes under field conditions than local Lesotho cultivars, Bolane and Makaloate. Russian wheat aphid resistant cultivars have proved to be a valuable strategy for managing Russian wheat aphid damage on wheat in South Africa.

\section{Conclusion}

Awareness of Russian wheat aphid biotypes and the link between Russian wheat aphid 
damage and yield would be an important step towards better wheat cultivation in Lesotho. This knowledge should be transferred to farmers in Lesotho through farmer's information days and agricultural extension officers visiting farmers. The farmers should be encouraged to adopt South African Russian wheat aphid resistant cultivars. This information will also be helpful in the selection process and breeding of local Lesotho cultivars and the incorporation of Russian wheat aphid resistance in selection of cultivars. This will improve overall yield and as a result will improve food security in Lesotho. This will also result in lower Russian wheat aphid pest pressure in the adjacent wheat production areas in the Eastern Free State, South Africa.

\section{Acknowledgements}

We would like to thank the Winter Cereal Trust for funding this research and National University of Lesotho, Roma and the ARC-Small Grain Institute, Bethlehem for facilities provided.

\section{References}

[1] Durr, H.J.R. (1983) Diuraphis noxia (Mordvilko) (Hemiptera: Aphididae), a Recent Addition to the Aphid Fauna of South Africa. Phytophylactica, 15, 81-83.

[2] Morrison, W.P. and Peairs, F.B. (1998) Response Model Concept and Economic Impact. In: Quisenberry, S.S. and Peairs, F.B., Eds., A Response Model for an Introduced Pest-The Russian Wheat Aphid (Homoptera: Aphididae). Thomas Say Publications in Entomology, Entomological Society of America, Lanham, Md, 1-11.

[3] Walters, M.C., Penn, F., Du Toit, F., Botha, T.C., Aalbersberg, K., Hewitt, P.H. and Broodryk, S.W. (1980) The Russian Wheat Aphid. Fmg S. Afr. Leaflet Series Wheat G3, 1-6.

[4] Havelka, J., Žurovcová, M, Rychlý, S. and Starý, P. (2013) Russian Wheat Aphid, Diuraphis noxia in the Czech Republic-Cause of the Significant Population Decrease. Journal of Applied Entomology, 138, 273-280. http://dx.doi.org/10.1111/jen.12068

[5] Basky, Z. and Eastop, V.F. (1989) Diuraphis Noxia in Hungary. Newsletter Barley Yellow Dwarf, 4, 34 .

[6] Starý, P. (1996) The Expansive Russian Wheat Aphid Diuraphis noxia (Kurdj.) Detected in the Czech Republic. Journal of Pest Science, 69, 19-20.

[7] Vošlajer, Z. (1999) Diuraphis noxia in the Czech Republic and Relationship Between the Migration and the Temperature Conditions. Proceedings of the 5 th International Conference on Pests in Agriculture, Part 2. Montpellier, 589-596.

[8] Randolph, T.L., Peairs, F.B., Koch, M., Walker, C.B., Stubbs, J.R., Quick, J.S. and Haley, S.D. (2005) Yield Response and Categories of Resistance to Russian Wheat Aphid in Four Dn4Hard Red Winter Wheat Cultivars. Journal of Economic Entomology, 98, 588-594. http://dx.doi.org/10.1603/0022-0493-98.2.588

[9] Tolmay, V.L., Lindeque, R.C. and Prinsloo, G.J. (2007) Preliminary Evidence of a Resistance-Breaking Biotype of the Russian Wheat Aphid, Diuraphis noxia (Kurdjumov) (Homoptera: Aphididae), in South Africa. African Entomology, 15, 228-230. http://dx.doi.org/10.4001/1021-3589-15.1.228

[10] Jankielsohn, A. (2011) Distribution and Diversity of Russian Wheat Aphid (Hemiptera: Aphididae) Biotypes in South Africa and Lesotho. Journal of Economic Entomology, 104, 1736-1741. http://dx.doi.org/10.1603/EC11061 
[11] Jankielsohn, A. (2014) The Russian Wheat Aphid. Farmer's Weekly, 17 January 2014, 22-23.

[12] National Statistical System of Lesotho (2014) Statistical Yearbook 2014. No 18: 2014. Bureau of Statistics, Maseru, Lesotho.

[13] Rosenblum, M.L., Ts'iu, J. and Moletsane, M. (1999) Farmers' Wheat (Triticum aestivum) Varieties in the Highlands of Lesotho. National department of Agriculture, Agricultural Information Centre. http://www.doa.agric.za/

[14] Tolmay, V.L. (1995) The Inheritance and Mechanisms of Russian Wheat Aphid (Diuraphis noxia) Resistance in Two Triticum aestivum Lines. M.Sc. Thesis, University of the Orange Free State, Bloemfontein.

[15] Marasas, C.N., Anandajayasekeram, P., Millard, S. and van Rooyen, C.J. (2005) Farm-Level Adoption and Impact of Agricultural Technology: The Case of Russian Wheat Aphid Resistant Cultivars in South Africa. S. Afr. Tydskr. Landbuvoorl/South African Journal of Agricultural Extension, 34, 318-333.

[16] Schotzko, D.J. and Bosque-Pérez, N.A. (2000) Seasonal Dynamics of Cereal Aphids on Russian Wheat Aphid (Homoptera: Aphididae) Susceptible and Resistant Wheats. Journal of Economic Entomology, 93, 975-981. http://dx.doi.org/10.1603/0022-0493-93.3.975

[17] Xinzhi, N. and Quisenberry, S.S. (2006) Diuraphis noxia and Rhopalosiphum padi (Hemiptera: Aphididae) Interactions and Their Injury on Resistant and Susceptible Cereal Seedlings. Journal of Economic Entomology, 99, 551-558.

http://dx.doi.org/10.1603/0022-0493-99.2.551

[18] Randolph, T.L., Peairs, F.B., Kroening, M.K., Armstrong, J.S., Hammon, R.W., Walker, C.B. and Quick, J.S. (2003) Plant Damage and Yield Response to the Russian Wheat Aphid (Homoptera: Aphididae) on Susceptible and Resistant Winter Wheats in Colorado. Journal of Economic Entomology, 96, 352-360. http://dx.doi.org/10.1093/jee/96.2.352

[19] SAGL (2015) South African Wheat Crop, Quality Report, 2013/2014 Season. The South African Grain Laboratory, NPC, South Africa.

Submit or recommend next manuscript to SCIRP and we will provide best service for you:

Accepting pre-submission inquiries through Email, Facebook, LinkedIn, Twitter, etc. A wide selection of journals (inclusive of 9 subjects, more than 200 journals)

Providing 24-hour high-quality service

User-friendly online submission system

Fair and swift peer-review system

Efficient typesetting and proofreading procedure

Display of the result of downloads and visits, as well as the number of cited articles Maximum dissemination of your research work

Submit your manuscript at: http://papersubmission.scirp.org/

Or contact ae@scirp.org 